\title{
Governing the Environmental Impact of Dredging: Consequences for Marine Biodiversity in the Niger Delta Region of Nigeria
} \author{
Williams ${ }^{3}$ \\ ${ }^{1}$ Bayelsa State Ministry of Health, Nigeria \\ ${ }^{2}$ Department of Community Medicine, Environmental Health Unit, Niger Delta University, Nigeria \\ ${ }^{3}$ Department of Geography and Environmental Management, Niger Delta University, Nigeria
}

Okoyen Ebikapaye ${ }^{1}$, Raimi Morufu Olalekan ${ }^{1,2 *}$, Omidiji Adedoyin Oluwatoyin ${ }^{3}$ and Ebuete Abinotami

Submission: September 25, 2020; Published: October 29, 2020

*Corresponding author: Raimi Morufu Olalekan, Bayelsa State Ministry of Health, Department of Community Medicine, Environmental Health Unit, Niger Delta University, Bayelsa State, Nigeria

\begin{abstract}
The attention of most scholars and stakeholders is far drawn from the devastation of the environmental consequences caused by dredging related activities, which has necessitated sand filling and pilling including skewed national government policies, which has resulted to fundamental concern to halt species extinction, a situation which ecologist are not at ease with. Emphasis has been focused on alterations in the chemistry of the environment. They are worried with the numerous vanished creatures and saddened, often angered by their extinction. Man has directly or indirectly been the cause of the extinction, including the issues of depletion and degradation impact on the environment, thereby, leading to restrictions in the size, density, and distribution of organisms that threaten the biodiversity, resilience, or provision of ecosystem services. As soon as the functionally significant components of an ecosystem are missing, it is extremely challenging to identify and understand ecological thresholds. The extent and intensity of human disturbance to oceanic ecosystems is a significant threat to both structural and functional biodiversity and in many cases this has virtually eliminated natural systems that might serve as baselines to appraise these impacts. It is therefore recommended that effective management of dredging problems in the Niger delta will require enforcement of relevant environmental laws, environmental monitoring, as it help limits the huge expenses on habitat clean-up exercises and restoration programs and critical habitats should be banned or carried out in such a manner as to protect the area or limit dredging to the lowest ecological damage. This should be pressure on all oil companies and relevant stakeholders to discontinue with dredging related activities. Petrochemical such as oils and other hydrocarbon should not be present in the aquatic environment in concentration that can cause tainting of edible aquatic organism, form visible deposits on shoreline and bottom sediment or be detected as a visible film/sheen or discoloration.
\end{abstract}

Keywords: Dredging; Environmental impact; Ecological damage; Critical habitats; Bio-complexity; Bioturbation; Niger Delta

\section{Introduction}

The Niger Delta is the life wire of the Nigerian economy, an important region that has been very seriously affected by oil exploration and production. Large channels have been dredged in many places to float oil rigs and lay pipelines. While the Niger Delta is located in the Gulf of Guinea in the Atlantic Coast of southern Nigeria precisely where River Niger divides into numerous tributaries (Figure 1). Regarded as the second largest delta in the world with a coastline spanning about 450 kilometres terminating at the Imo River entrance, the region span over 20,000 square kilometers and it has been described as the largest wetlands in Africa and among the three largest in the world. About 2,370 square kilometres of the Niger Delta area consist of rivers, creeks and estuaries and while stagnant swamp covers about 8,600 square kilometers [1-6]. In the last two decades, the Niger Delta has enjoyed rare spotlight in the Nigerian political discourse. The reasons for this are not connected to its being the second largest delta in the world or because it consists of rivers, creeks and stagnant swamp, but because the Niger Delta has been a victim of its resources.

The oil wealth and the politics of its exploration and exploitation, make the Niger Delta a study on paradox. The Niger Deltas resource oil production makes Nigeria the seventh largest producer in the world and the fifth exporter of oil in the United State. However, the region account for nearly 95\% of Nigeria's foreign exchange earnings, $40 \%$ of gross domestic product (GDP), and 84 percent of government expenditure is undeniably a victim 
of "oil resources curse" [7]. It is the most underdeveloped region in Nigeria with widespread and entrenched poverty. The people are not only poor, but their environment has also become the most environmentally assaulted area with major impact as a result of dredging activities. With over 5200 oil wells drilled in the areas, and about 2 million barrels of crude oil per day that passed through about 275 flow station and exported through ten terminals $[1,8-10]$, the region has been subjected to the most environmental abuse recorded in sub-Saharan Africa. Hence, human activity is having a significant and escalating impact on the global environment, they also reduce the resilience and capacity of ecosystems for delivery of vital ecosystem services, including food and water provision and protection from natural disasters.

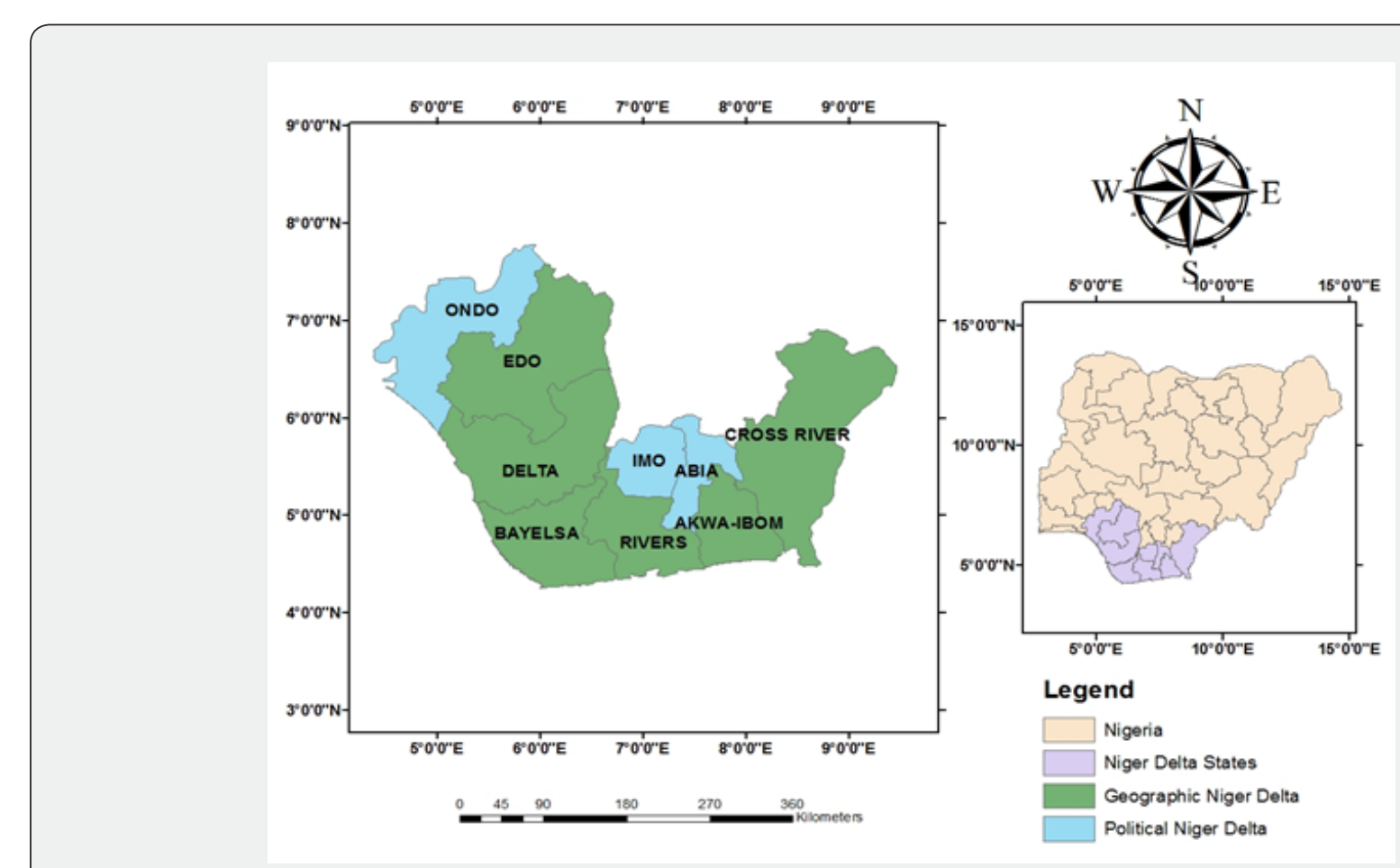

Figure 1: Map of Nigeria numerically showing states typically considered to be part the Niger Delta, including: Abia, Akwa Ibom, Bayelsa, Cross Rivers, Edo, Delta, Imo, Ondo and Rivers.

Often times, environmental degradation is a major cause of productivity losses and poor human health in the Niger Delta, and environmental degradation issues are of topical concern to communities in the area. While, human altered these aquatic systems and ruin the life histories of many species, even those that he finds desirable interest. Because of their partially enclosed nature, estuaries seem especially vulnerable to this anthropogenic perturbation. As many currently experience remarkable rates of qualitative and quantitative degradation, environmental threats and impacts are associated with growing human populations; as population dynamics are key drivers of local and global environmental change. The resulting growing populations leads to increased consumption of land use natural resources, posing additional environmental pressures in terms of uses and misuses of aquatic systems that have caused considerable increase in their degradation (Table 1) [11-14]. Consequently, their importance has continually diminished and there is an overall alteration in ecological integrity. Very often, the duration, magnitude and extent of undetected anthropogenic perturbations may be so enormous that there is limited opportunity for natural recovery of impacted aquatic systems without serious restoration efforts. Moreover, species and whole communities are being lost in an alarming rate in some cases even before they can be identified and long before they can be studied (Stiassny, 1996). There is thus an obvious need for organized environmental monitoring exercises if aquatic systems and their resources are to be protected from the adverse effects of human-induced perturbations.

The aquatic ecosystem parameters that are commonly affected by anthropogenic perturbations are summarized in Table 2. The integrated impacts of these human mediated factors cause considerable perturbations of a minimum of eight major components of aquatic systems viz: ecohydrological regime, habitat area, habitat quality, water quality, substrate quality, energy source, biotic interactions and resources exploitation. These variables play critical roles in determining the ecological integrity of aquatic systems (Figure 2). 


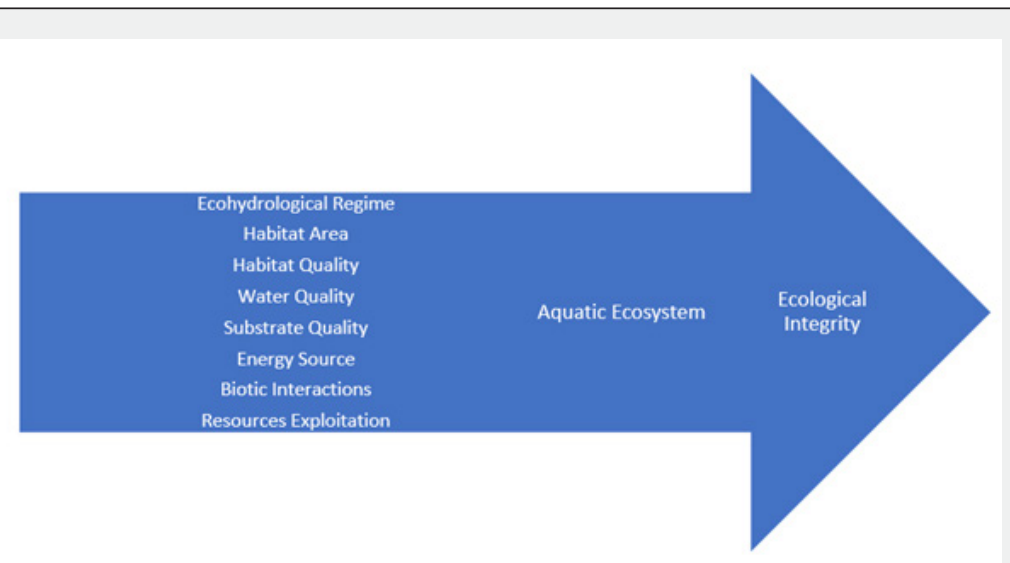

Figure 2: Primary variables that affect the ecological integrity of aquatic systems.

Table 1: Major anthropogenic perturbations of aquatic systems.

\begin{tabular}{|c|c|}
\hline Human Factors & Perturbation Processes \\
\hline \multirow{16}{*}{ Water Utilization } & Hydroelectric power generation/reservoir construction \\
\hline & Water abstraction for agricultural, domestic and industrial purposes \\
\hline & Extraction of common salt \\
\hline & Navigation and associated harbor/port activities \\
\hline & Dredging of navigational routes \\
\hline & Channelization \\
\hline & Levee construction \\
\hline & Subsurface oil pipeline construction \\
\hline & Constructions of the oil rigs/platforms \\
\hline & Sundry military operations \\
\hline & Fisheries: subsistence, artisanal, industrial and recreational fisheries sub-sectors \\
\hline & Aquaculture: cage/pen culture, rice field culture, mariculture \\
\hline & Solid waste disposal: municipal/industrial wastes \\
\hline & Industrial/municipal/domestic effluents inputs \\
\hline & Oil spillage/other liquid contaminants \\
\hline & Unintentional introduction of exotic species \\
\hline Marginal Land & Wildlife hunting \\
\hline \multirow{12}{*}{ Utilization } & Deforestation, resulting from irrational extraction of forest products \\
\hline & Conversion for crop agriculture \\
\hline & Conversion for aquaculture ponds \\
\hline & Pasture land for grazing livestock \\
\hline & Villagization: creation of village centers \\
\hline & Urbanization/industrialization \\
\hline & Infrastructure development \\
\hline & Canalization \\
\hline & Substrate extraction -limestone, peat, clay, sand and gravel \\
\hline & Surface oil pipeline construction \\
\hline & Construction of oil rigs/platforms \\
\hline & Mineral extraction: petroleum and associated natural gas; gold mining \\
\hline
\end{tabular}




\section{Insights in Mining Science \& Technology}

\begin{tabular}{|l|c|}
\hline Socioeconomic & Demographic changes e.g. increased population \\
\hline \multirow{4}{*}{ Pressures } & Standard of living/sanitation \\
\cline { 2 - 3 } & Housing conditions/human health \\
\cline { 2 - 3 } & Demand for food/better living conditions \\
\cline { 2 - 3 } & Employment \\
\cline { 2 - 3 } & Outdoor recreation \\
\cline { 2 - 3 } & Tourism \\
\cline { 2 - 3 } & Intentional introduction of exotic species \\
\hline
\end{tabular}

Sources: Adapted from Richard and Goodluck [39].

Table 2: Parameters affected by various anthropogenic perturbations of aquatic systems.

\begin{tabular}{|c|c|}
\hline Aquatic Parameters & Anthropogenic Perturbation \\
\hline \multirow{10}{*}{ Ecohydrological Regime } & Impoundments: - hydroelectric power generation \\
\hline & Irrigation \\
\hline & Interbasin water transfer \\
\hline & Surface/ground water abstraction \\
\hline & Urbanization/villagization: infilling/land reclamation \\
\hline & Industrialization: Infilling/land reclamation \\
\hline & Agriculture: Infilling/land degradation \\
\hline & Dredging of navigational routes \\
\hline & Channelization: channel straightening, widening and deepening \\
\hline & Canalization: Land fragmentation; interbasin water transfer \\
\hline Habitat Area/Habitat & Loss and/or fragmentation of habitat due to: \\
\hline \multirow{6}{*}{ Destruction } & a) Urbanization/villagization: Infilling/reclamation \\
\hline & b) Industrialization: Infilling/reclamation \\
\hline & c) Road and rail construction \\
\hline & d) Oil pipeline construction \\
\hline & e) Crop agriculture: conversion of wetland into arable land; expansion of cultivated land \\
\hline & f) Aquaculture: conversion of wetland into fish ponds \\
\hline \multirow{2}{*}{ Habitat Quality } & Channelization: channel straightening, widening and deepening \\
\hline & Embankments: bank stabilization e.g. levees, dikes, wing dams \\
\hline \multirow{7}{*}{ Water Quality } & Urbanization: input of municipal surface runoff; input of solid wastes; input of microbial pathogens from human sewage \\
\hline & Industrialization: input of fertilizers and agrochemicals; thermal/cold water; heavy metals \\
\hline & Aquaculture: input of fertilizers, growth hormones, chemicals and waste water \\
\hline & Agriculture: input of fertilizers from cultivated lands and animal manure \\
\hline & Disposal of dredging spoils (sludge) \\
\hline & Dumping of radio-active wastes \\
\hline & Oil pollution: petroleum hydrocarbons \\
\hline \multirow{2}{*}{ Substrate Quality } & Dredging: decrease in the stability and diversity of the benthic substrate; sedimentation \\
\hline & Pollution: accumulation of heavy metals and toxicants \\
\hline \multirow{4}{*}{ Energy Source } & Removal of riparian vegetation results in a decline in allochthonous energy input \\
\hline & Dredging adversely affects the microbenthic invertebrates \\
\hline & Anthropogenic eutrophication results in algal blooms \\
\hline & Pollution: destruction of both primary and secondary food sources \\
\hline
\end{tabular}




\begin{tabular}{|c|c|}
\hline Biotic Interactions & $\begin{array}{c}\text { Removal of riparian vegetation, dredging, anthropogenic eutrophication, pollution (see energy source above) and intro- } \\
\text { duction of exotic species }\end{array}$ \\
\hline Resources Exploitation & $\begin{array}{r}\text { Overexploitation of living resources via finfish fishing, octopus fishing, shellfish collection, sea-cucumber collection, sea- } \\
\text { weed collection, coral mining, curio collection, hunting, grazing and tourism }\end{array}$ \\
\hline
\end{tabular}

Sources: Adapted from Richard and Goodluck [39].

While, changes in wealth and age structure also alter lifestyle, consumption habits and diet, all of which can have environmental consequences [7, 15-18]. The world's population has grown from less than 4 billion in 1970 to 7 billion today. By 2050, the United Nations estimates that the global population will reach almost 9.2 billion people, an additional 2.2 billion people [19]. The world's population is now over seven billion people and is tracking toward nine billion come 2050 [19]. Many environmental problems arise from human-induced habitat modification, resource use, and disposal of waste. Examples comprise air and water pollution, impacts on biodiversity as a result of direct influences (e.g., hunting and fishing) or indirect activities (habitat clearing, pesticide use), and reduction of freshwater flows as a result of diversion (irrigation) or storage (dams) for human use $[13,16,20-22]$.

Although great emphasis has been paid to the decline in species diversity in terrestrial ecosystems, it is apparent that there have also been substantial changes in the diversity of aquatic systems, albeit changes that may not be so readily detected. A common perception of marine seafloor biodiversity reflects a disproportionate interest in hard bottoms such as coral reefs, kelp forests, and therocky intertidal.Thisbias is understandable because these hard-bottom communities lend themselves to terrestrial comparisons and ecological studies. However, nearly $70 \%$ of the earth's seafloor is composed of marine soft sediments $[23,24]$. These soft-sediment habitats can be highly heterogeneous due to the interactions between broad-scale factors (e.g., hydrodynamic and nutrient regimes) and smaller-scale physical and biological features; nonetheless, the apparent three-dimensional habitat structure imposed by this heterogeneity may not be as obvious as that observed on hard-bottom habitats. Although these habitats are not always appearing as highly structured as some terrestrial or marine reef habitats, they support an extremely high species diversity [24-26]. Additionally, organisms that inhabit the sediments create much of the structure in soft-sediment habitats, ranging from the micro-scale changes around individual animal burrows to the formation of extensive biogenic reefs. As well as adding substantively to the variety of species found on earth, soft sediment marine organisms have functional roles crucial to many ecosystem processes. However, the disturbance regimes play an important role in influencing biodiversity [27].
In marine benthic habitats small-scale natural disturbance plays a remarkable role in influencing communities by generating patchiness [28,29]. Many of the small-scale disturbances that impact benthic communities and generate heterogeneity result from the biological activities of organisms that live in or feed on the seafloor. The spatial heterogeneity created by local disturbance events can account for resource patchiness [30], and ubiquity of opportunistic species in soft-sediment habitats. This heterogeneity is an important component of the functioning of ecological systems [31] and has consequences for diversity maintenance and population stability for community, and ecosystem levels [32]. The natural disturbance fact is important to soft-sediment communities that has led to the suggestion that fishing disturbance can positively affect biodiversity.

Dredging is a critical operation that is regularly carried out to preserve safe passage for boats and ships at ports and harbors $[33,34]$. In other words, dredging is significant for maintaining and performance of harbor operations, i.e., For the import and export of goods. However, the removal of dredged spoil at sea can potentially affect the marine environment and its ecosystems $[35,36]$. The dredging and dumping of spoils at sea will inevitably increase turbidity levels and settlement of fine sediment over an extended area. This can propagate to a large area around the dumped location. The impacts of this loss of land and fisheries potential has been studied at Louisiana State University [37]. It is estimated that nearly $1-2.6 \%$ of Barataria Basin (around $5,700 \mathrm{~km}^{2}$ or 2,200 square miles) has been directly removed by dredging. If the dredged spoils area is combined (as this land also is lost from marsh production), perhaps $10 \%$ of the area could be lost due to biotic production.

The total area adversely affected is almost $20 \%$ in combination with secondary adverse effects, such as loss of sheet flow, are included. Once the canals are dug, they tend to expand each year from erosion [38] thus the effects persist even after dredging or extraction ceases. Also, dredging results in the direct removal of intact benthic sediments, the habitat upon which the survival of many species of animals, plants, and bacteria depends. A similar effect from dredging was observed on shallow-water benthos in a tropical estuary and the loss in benthic algae biomass (i.e. standing crop) was attributed to dredging. The main sources of environmental stress from dredging activities are the formation 
of airborne dust, solid waste, noise, and chemical discharges released into nearby bodies of waters. A well comprehensive review will cover all these impacts associated with dredging activities in other areas of the Niger Delta region of Nigeria. It also, interferes with physiological processes, suggesting that temperature is very significant in determining the rates, and in some cases even the presence of significant biological functions such as photosynthesis, respiration, enzyme activity, feeding, and reproduction. Hence, any change in water temperature affects the metabolism of aquatic plants, bacteria, and cold-blooded animals since they cannot perform their internal heat balance actively.

Henceforth, the continuous dumping of spoils can interfere with the smothering of the seabed environment, coral reefs, egglaying nests of fish and can disturb their navigations. Finally, dredging and dumping alter the topography of the seabed during dredging and dumping locations and can therefore change the local flow patterns. The impact of the dumped spoils on water quality is also affected by the concentration of suspended material. The chemical, physical, physiological, and behavioral changes can be combined to change and affect entire aquatic ecosystems through changing primary and secondary production, community respiration, species composition, biomass, and nutrient flows. As a result, dredging and its related activities should be monitored, controlled and their impacts on the marine environments should be assessed, maintained and safeguarded through appropriate and effective management strategies.

Impacts are summarized as follows:

a) Introduction of hard substrata into soft-sediment ecosystems (shipwrecks, clinkers, trash, cables, pipelines, submarine structures).

b) Organic enrichment (sewage dumping, organic cargo on sunken vessels, dumping of by catch).

c) Chemical pollution (oil, drilling muds and other oil/ gas production chemicals, industrial chemicals, pharmaceuticals, munitions including chemical weapons).

d) The introduction of heavy metals and other toxins into the environment during the dredging operations.

e) Excessive sediment disruption with sometimes heavy increases in turbidity-associated with the dredging of channels for tankers and drill rigs.

f) Radiochemical pollution.

g) Biomass removal (fishing, bioprospecting, scientific research).

h) Mechanical disturbance (bottom fishing, cable laying, submarine pipelines, scientific research).

i) Light pollution (industrial activity, scientific research). j) Acoustic disturbance (oil and gas exploration, military activity, scientific research).

k) The provision of protein for human consumption and the ecosystems that sustain fisheries are clear examples of the products and functions of marine ecosystems that benefit humankind. Other processes in which marine benthos play important roles include their influence on sediment stability, water column turbidity, nutrient and carbon processing, and contaminant sequestering, as well as the provision of pharmaceuticals and nutraceuticals and recreational and amenity values.

l) Suspended sediments reduce primary productivity by limiting light penetration into the water column. However, many nearshore coastal sediments are also badly polluted with a variety of hydrocarbons, metals, pesticides, etc. and the suspension and movement of such polluted sediments can pose a significant threat to biological communities [8-10,12,22].

m) The disposal of polluted dredge spoil alone is also a significant problem. Poorly planned and managed dredging has resulted in the death of many miles of coral reefs.

n) This loss to the ecosystem occurs when there are restrictions in the size, density, and distribution of organisms that threaten the biodiversity, resilience, or provision of ecosystem services. Once the functionally important components of an ecosystem are missing, it is extremely difficult to identify and understand ecological thresholds. The extent and intensity of human disturbance to oceanic ecosystems is a significant threat to both structural and functional biodiversity and in many cases, this has virtually eliminated natural systems that might serve as baselines to evaluate these impacts [39].

\section{Addressing the Issues}

Most of these changes have arisen as a result of the quest of man to improve his socioeconomic and technological status. Because of the fact that mankind will always continue to improve on these endeavors so as to make life meaningful and the world better to live in, the aquatic environment will for a long time be under intense pressure. Of these, the most serious present impacts arise from deep-sea bottom fisheries that target low species productivity. Low species productivity are those considered by slow growth rates, high longevity, and sporadic reproduction when they have accumulated enough energy for offspring production. Undisturbed coastal regions are uniquely rich biotic resources that are valued highly by society. They are also areas that is important and often necessary industries must be maintained and utilized. Some of these are large-scale systems for the production, processing, and distribution of commercial energy. Since dredging-related activities have been known to generate severe and persistent environmental impacts, it is important to understand how and why they affect the integrity of coastal ecosystems as they do and to determine the adequacy of 
attempting to mitigate their effects. This is especially imperative when the aquatic and semiaquatic systems is to continue to provide us with the various aesthetic, recreational, and fishery resources they have given us in the past. These benefits confirm some legitimate uses of the coastal zone that should be protected or safeguarded by appropriate management strategies. Much of the current negative impact connected with dredging activities in the coastal zone is unwarranted and could have been avoided by more thoughtful planning. This is a condition that has resulted from man's inability to measure or characterize ecological stress, mismanagement of our technical resources, and/or from the inadequacy of appropriate decision-making.

Likewise, the ecological consequences of human activity on marine environment require an understanding of the broad scale forcing functions as well as knowledge of the natural and life history characteristics of each individual species. There are winners and losers in responding to the ecological disturbance, but the big question is understanding the ecological heterogeneity and its role in transforming the consequences of habitat disturbance to ecosystem processes. It is necessary to better understand the implications of natural and anthropogenic habitat fragmentation and how it relates to the intensity and frequency of disturbance. Interesting empirical and theoretical studies that solves this problem should integrate biogeochemistry, hydrodynamics, and ecology. Site history and the effect of multiple stresses will be predominantly remarkable in many areas in order to address the role of the resident species assemblage and environmental context in affecting disturbance-recovery dynamics in fragmented habitats. Once the functionally important components of an ecosystem are missing, it is extremely difficult to identify and understand ecological thresholds that are violated beyond the point of recovery, at which point the anthropogenic disturbances are less evident. Some knowledge of these issues is necessary to resolve this more important question. Also, environmental impact assessment should be conducted as detailed and specified by the regulatory authority.

The study if well executed will serve all concern stakeholders in no small measure. The document will serve as a management tool to guide decision making during start up and decommissioning of dredging project. Similarly, there is need for the development of an integrated monitoring framework from dredging related activities to provide the fundamental implement for decision making through integrated multidisciplinary approach such as environmental scientists, planners and managers. Consequently, a monitoring scheme should be expedient and uncomplicated. It should involve the use of a standard monitoring team that has the expertise to investigate and evaluate the apparent or potential effects of dredging related activities. The team should be acceptable to government authorities, community stakeholders, property owners, developers and other interest groups. The team membership should include inter alia experts in the fields of ecology, geography, biology, geology, fisheries, hydrochemistry, hydrology, engineering, sociology, economics, tourism, environmental laws and policies, including hydroinformatics. Ancillary team members may perhaps include public relations officers, policymakers, representatives of affected local communities, stakeholders, coast guards, wildlife rangers and police. The selection of the team members should be based strictly on qualification and experience. Very often unqualified and inexperienced personnel are appointed in order to limit operational cost. This should be strongly discouraged. Moreover, the composition of the team should be gender biased.

As many more effort is urgently needed to save the 100 species scientist fear are being extinguished every single day as humans deliberately or inadvertently destroy the natural system that sustain life on earth. Like any inheritance, biodiversity can flourish if well managed, or it can be squandered and lost. Today massive loss of species and habitat will be slowed only when the human community understand that nature is not an inferior to be exploited or an enemy to be destroyed but an ally requiring respect and replenishment. Hence, to reduce vulnerability, there is need for collective action on environmental protection and ecosystem balance, henceforth the collective drive for environmentalism. This is because every human society depends to a large extent on the biodiversity that are within its immediate environment. Hence, an effective weighing and aggregating system of environmental evaluation could be devised.

\section{Competing Interests}

We affirm that we have no conflict of interest that may be alleged as prejudicing the impartiality of the study reported. This researcher did not receive special assistance from government, not-for-profit sectors or commercial institutions.

\section{References}

1. Obasanjo O (2004) Address to the Niger Delta Youth Stakeholder. Workshop, Port-Harcourt.

2. Abdulraheem AFO, Olalekan RM, Abasiekong EM (2018) Mother and father adolescent relationships and substance use in the Niger delta: a case study of twenty-five (25) communities in Yenagoa local government of Bayelsa state, Nigeria. Sociol Int J 2(6): 541-548.

3. Premoboere EA, Raimi MO (2018) Corporate Civil Liability and Compensation Regime for Environmental Pollution in the Niger Delta International Journal of Recent Advances in Multidisciplinary Research 5(6): 3870-3893.

4. Olalekan RM, Adedoyin OO, Ayibatonbira A, Babatunde A, Odipe OE, al. (2019) Digging deeper evidence on water crisis and its solution in Nigeria for Bayelsa state: a study of current scenario. International Journal of Hydrology 3(4): 244-257.

5. Raimi MO, Suleiman RM, Odipe OE, Salami JT, Oshatunberu M, et al (2019) Women Role in Environmental Conservation and Development in Nigeria. Ecology \& Conservation Science 1(2).

6. Olalekan RM, Oluwatoyin OA, Olawale SH, Emmanuel OO, Olalekan AZ (2020) A Critical Review of Health Impact Assessment: Towards Strengthening the Knowledge of Decision Makers Understand Sustainable Development Goals in the Twenty-First Century: Necessity 
Today; Essentiality Tomorrow. Research and Advances: Environmental Sciences 1: 72-84.

7. Olalekan RM, Oluwatoyin O, Olalekan A (2020) Health Impact Assessment: A tool to Advance the Knowledge of Policy Makers Understand Sustainable Development Goals: A Review. ES Journal of Public Health 1(1).

8. Morufu R, Clinton E (2017) Assessment of Trace Elements in Surface and Ground Water Quality. LAP Lambert Academic Publishing. Mauritius.

9. Raimi MO, Sabinus CE (2017) An Assessment of Trace Elements in Surface and Ground Water Quality in the Ebocha-Obrikom Oil and Gas Producing Area of Rivers State, Nigeria. International Journal for Scientific and Engineering Research (Ijser): 8(7).

10. Olalekan RM, Omidiji AO, Nimisngha D, Odipe OE, Olalekan AS (2018) Health Risk Assessment on Heavy Metals Ingestion through Groundwater Drinking Pathway for Residents in an Oil and Gas Producing Area of Rivers State Nigeria. Open Journal of Yangtze Gas and Oil 3: 191-206.

11. King RP, Ekeh IB (1997) Environmental effects of instream sand excavation on the hydrochemistry of a Nigerian headwater stream. Int J Sur Min Recl Env 11: 75-78.

12. Raimi MO (2019) 21 $1^{\text {st }}$ Century Emerging Issues in Pollution Control. $6^{\text {th }}$ Global Summit and Expo on Pollution Control, Amsterdam, Netherlands.

13. Olalekan RM, Omidiji AO, Williams EA, Christianah MB, Modupe 0 (2019) The roles of all tiers of government and development partners in environmental conservation of natural resource: a case study in Nigeria. MOJ Ecology \& Environmental Sciences 4(3): 114-121.

14. Raimi MO, Bilewu 00, Adio Z, Abdulrahman H (2019) Women Contributions to Sustainable Environments in Nigeria. Journal of Scientific Research in Allied Sciences 5(4): 35-51.

15. Suleiman RM, Raimi MO, Sawyerr HO (2019) A Deep Dive into the Review of National Environmental Standards and Regulations Enforcement Agency (NESREA) Act. International Research Journal of Applied Sciences 1(4): 108-125.

16. Olalekan RM, Dodeye EO, Efegbere HA, Odipe OE, Deinkuro NS, et al. (2020) Leaving No One Behind? Drinking-Water Challenge on the Rise in Niger Delta Region of Nigeria: A Review. Merit Research Journal of Environmental Science and Toxicology.

17. Ajayi FA, Raimi MO, Steve AOC, Adeniji AO, Adebayo PA (2020) Policy Responses to Addressing the Issues of Environmental Health Impacts of Charcoal Factory in Nigeria: Necessity Today; Essentiality Tomorrow. Communication, Society and Media 3(3).

18. Adedoyin OO, Olalekan RM, Olawale SH, Odipe OE (2020) A review of environmental, social and health impact assessment (Eshia) practice in Nigeria: a panacea for sustainable development and decision making MOJ Public Health 9(3): 81-87.

19. UN (2011) World Population Prospects: The 2010 Revision. New York

20. Raimi MO, Adeolu AT, Enabulele CE, Awogbami SO (2018) Assessment of Air Quality Indices and its Health Impacts in Ilorin Metropolis, Kwara State, Nigeria. Science Park Journals of Scientific Research and Impact 4(4): 60-74.

21. Raimi MO, Adio ZO, Odipe OE, Timothy KS, Ajayi BS, et al. (2020)
Impact of Sawmill Industry on Ambient Air Quality: A Case Study of Ilorin Metropolis, Kwara State, Nigeria. Energy and Earth Science 3(1).

22. Isah HM, Raimi MO, Sawyerr HO, Odipe OE, Bashir BG, et al. (2020) Qualitative Adverse Health Experience Associated with Pesticides Usage among Farmers from Kura, Kano State, Nigeria. Merit Research Journal of Medicine and Medical Sciences 8(8): 432-447.

23. Wilson WH (1991) Competition and predation in marine soft-sediment communities. Annu Rev Ecol Syst 21: 221-241.

24. Snelgrove PVR (1999) Getting to the bottom of marine biodiversity: sedimentary habitats-ocean bottoms are the most widespread habitat on Earth and support high biodiversity and key ecosystem services. Bioscience 49: 129-38.

25. Coleman N, Gason ASH, Poore GCB (1997) High species richness in the shallow marine waters of southeast Australia. Mar. Ecol Prog Ser 154: 17-26.

26. Gray JS, Poore GCB, Ugland KI, Wilson RS, Olsgard F, et al. (1997) Coastal and deep-sea benthic diversities compared. Mar Ecol Prog Ser 159: 97-103.

27. Huston MA (1994) Biological Diversity: The Coexistence of Species on Changing Landscapes. Cambridge: Cambridge Univ. Press pp. 681.

28. Dayton PK (1994) Community landscape: scale and stability in hard bottom marine communities. pp. 289-332.

29. Hall SJ, Raffaelli D, Thrush SF (1994) Patchiness and disturbance in shallow water benthic assemblages. pp. 333-375.

30. Van BGR (1982) Experimental analysis of structural regulation in a marine sand community exposed to oceanic swell. Ecol. Monogr 52(3): 283-305.

31. Giller PS, Hildrew AG, Raffaelli D (1994) Aquatic Ecology: Scale, Pattern and Process. Oxford: Blackwell Sci. pp. 649.

32. Loehle C, Li BL (1996) Habitat destruction and the extinction debt revisited. Ecol Appl 6(3): 784-789.

33. Bolam SG. Rees HL (2003) Minimizing impacts of maintenance dredged material disposal in the coastal environment: A habitat approach. Environ. Manag 32(2): 171-188.

34. Bellas J, Nieto O, Beiras R (2011) Integrative assessment of coastal pollution: Development and evaluation of sediment quality criteria from chemical contamination and ecotoxicological data. Cont. Self Res 31(5): 448-456.

35. Aarninkhof S, Luijendijk A (2010) Safe disposal of dredged material in an environmentally sensitive environment. Port Technol Int 47: 39-45.

36. Erftemeijer PLA, Riegl B, Hoeksema BW, Todd PA (2012) Environmental impacts of dredging and other sediment disturbances on corals: a review. Mar Pollut Bull 64(9): 1737-1765.

37. Craig NJ, Day JW (1977) Cumulative Impact studies in the Louisiana Coastal Zone: Eutrophication, Land Loss. Final Rep. to Louisiana State Planning Office.

38. Odubo TR, Raimi MO (2019) Resettlement and Readjustment Patterns of Rural Dwellers During and After Flood Disasters in Bayelsa State Nigeria. British Journal of Environmental Sciences 7(3): 45-52.

39. Richard PK, Goodluck EJ (2003) Aquatic Environmental Perturbations and Monitoring. First Edition. African Experience. 
(C) This work is licensed under Creative Commons Attribution 4.0 License
DOI: $10.19080 /$ IMST.2020.02.555586
- Quality Editorial service

- Swift Peer Review

- Reprints availability

- E-prints Service

- Manuscript Podcast for convenient understanding

- Global attainment for your research

- Manuscript accessibility in different formats

( Pdf, E-pub, Full Text, Audio)

- Unceasing customer service

Track the below URL for one-step submission https://juniperpublishers.com/online-submission.php 